\title{
A Gynandromorph and Teratological Case in Spilomicrus sp. (Hymenoptera, Diaprioidea, Diapriidae)
}

\author{
Emerson Fraga Comério ${ }^{\bowtie}$, Nelson Wanderley Perioto ${ }^{2} \&$ Rogéria Inês Rosa Lara ${ }^{2}$
}

1. Universidade Estadual Paulista "Júlio de Mesquita Filho", Faculdade de Ciências Agrárias e Veterinárias de Jaboticabal - UNESP/FCAV, e-mail: emersoncomerio@hotmail.com (Autor para correspondência ${ }^{\varpi}$ ). 2. APTA Centro Leste / Universidade Estadual Paulista “Júlio de Mesquita Filho", Faculdade de Ciências Agrárias e Veterinárias de Jaboticabal - UNESP/FCAV, e-mail: nerioto@gmail.com, rirlara@yahoo.com.br.

\section{EntomoBrasilis 8 (3): 249-252 (2015)}

Abstract. This study reports the occurrence of antennae with female and male characteristics in a female of Spilomicrus sp. (Hymenoptera, Diaprioidea, Diapriidae) collected in Parque Estadual Intervales, Ribeirão Grande, São Paulo, Brazil, as well as malformations in one of the antennas, which are described and illustrated.

Keywords: Diapriinae; Gynandromorphs; Morphological Abnormality; Spilomicrini; Teratology.

\section{Um Caso de Ginandromorfia e Teratologia em Spilomicrus sp. (Hymenoptera, Diaprioidea, Diapriidae)}

Resumo. Este estudo relata a ocorrência de antenas com características femininas e masculinas em um exemplar fêmea de Spilomicrus sp. (Hymenoptera, Diaprioidea, Diapriidae) coletado no Parque Estadual Intervales, Ribeirão Grande, São Paulo, Brasil, assim como malformações em uma das antenas, que são aqui descritas e ilustradas.

Palavras-Chave: Anomalia Morfológica; Diapriinae; Ginandromorfismo; Spilomicrini; Teratologia.

0 ynandromorphs are sexually abnormal individuals that show deviant phenotypes in the expression of female and male characters, exhibited in the same tagmata or part of them. They are normally rare or very rare in nature, thus not frequently collected (TURrisi \& BORSATO 2008).

Among Hymenoptera, the gynandromorphism has been documented in Formicidae (WHEELER 1903; ADLERZ 1908; Berndt \& Kremer 1983; Scupola 1994), Diprionidae (Martini et al. 1999), Siricidae (Neumann 1970), Tenthredinidae (Peacock 1925), Trichogrammatidae (BESERra et al. 2003), Encyrtidae (Caltagirone 1970; Zhang \& Zhu 2007), Scelionidae (Huggert 1977), Chalcididae (Halstead 1988), Agaonidae (Pereira et al. 2003), Ichneumonidae (TARASCO 1996), Braconidae (Whiting \& Whiting 1927), Mutillidae (Maeklin 1956; Turrisi 1999), Eumenidae (COOPER 1959; Turrisi \& Borsato 2008), Sphecidae (Schneider \& Feitz 2003), Platygastridae (SAFAVI 1968) and Apoidea (LaidlaW 1932; LeClerq 1953; Akre et al. 1982; Nilsson 1987; Celary \& Wisniowski 2001; Ornosa et al. 2001; González 2004; WCISLO et al. 2004; EngEL 2007; LuCIA et al. 2009; MicheZ et al. 2009).

Teratology is the study of structural abnormalities, especially monstrosities and malformations (Torre-BuENo 1989). BALAZUC (1948) defined it as the study of monsters and SAvinI \& FURTH (2004) defined as monsters the specimens of a particular species with one or more exceptional anatomical particularities, incompatible with the generic characters or with characters of the suprageneric taxon to which the species belongs.

In Hymenoptera, teratological cases were reported by BALAZUC (1957), Fabritius (1968), Acosta \& Martinez (1984), Michel (1985), Borderá \& Tormos (1986), Tussac \& Balazuc (1991), Bessart (1993), Tussac (1994), Borsato (1995), Penteado-Dias et al. (2005) and Popovici et al. (2014).

In Diapriidae (Hymenoptera), abnormalities were reported in Trichopria verticillata (Letreille) that showed one male and one female antenna (Foerster, 1845); ChitTy (1905) reported a gynandromorph species of Spilomicrinae; Ceballos (1921) reported a specimen of Basalys macroptera (Kieffer) with the left side of the body with female characteristics and the right with male ones; OGLobin (1936) reported a female of Acanthopria sp. with the antennas male features; SzABó (1959) reported a case of a female of Monelata cincta (Haliday) with a male antenna withdeformed antennomeres; BIN (1972) reported a ginandromorph female of Trichopria Ashmead with a male antennae; BIN (1976) reported a female of Trichopria with teratological processes in head with only one compound eye, antenna and ocelli ande left mandible stunted; RAJMOHANA \& NARENDRAN (1999) reported a ginandromorph female of Trichopria with teratological segments in one antenna.

A This paper report teratological and gynandromorph female of Spilomicrus (Figure 1) collected in January 2010 in area of Atlantic Rainforest at Parque Estadual Intervales (24 ${ }^{\circ} 16^{\prime} 27.7^{\prime \prime} \mathrm{S}$ / 48 25 '19.3”W), Ribeirão Grande, São Paulo State, Brazil. Both antennas of the studied specimen had 13 segments. The right antennae, with female characteristics, has moderate, nonabrupt, multisegmented clava, antenommere 12 subequal in length to antenommere 13, with lateral pit, clavomeres slightly flattened ventrally, antenommeres 8 and 9 abnormals, not distinctly separated, and antenommere 3 with a teratoma (Figures 2. a,b);

Funding Agencies: Instituto Nacional de Ciência e Tecnologia dos Hymenoptera Parasitoides da Região Sudeste Brasileira (Hympar/ Sudeste - CNPq/Fapesp/Capes) 
T the left one, with male characteristics, wastypically filiform, with scattered short hairs, and antenommere 4 abnormal, without typical sharp longitudinal keel (Figure 2c). The others morphological characteristics were normal to females of Spilomicrus.
The examined specimen have been deposited in the collection LRRP - Coleção Entomológica do Laboratório de Sistemática e Bioecologia de Parasitoides e Predadores da APTA Ribeirão Preto, Ribeirão Preto, SP, Brazil (N.W. Perioto, curator). Permanent license to collect zoological material (IBAMA) number 16473-1.

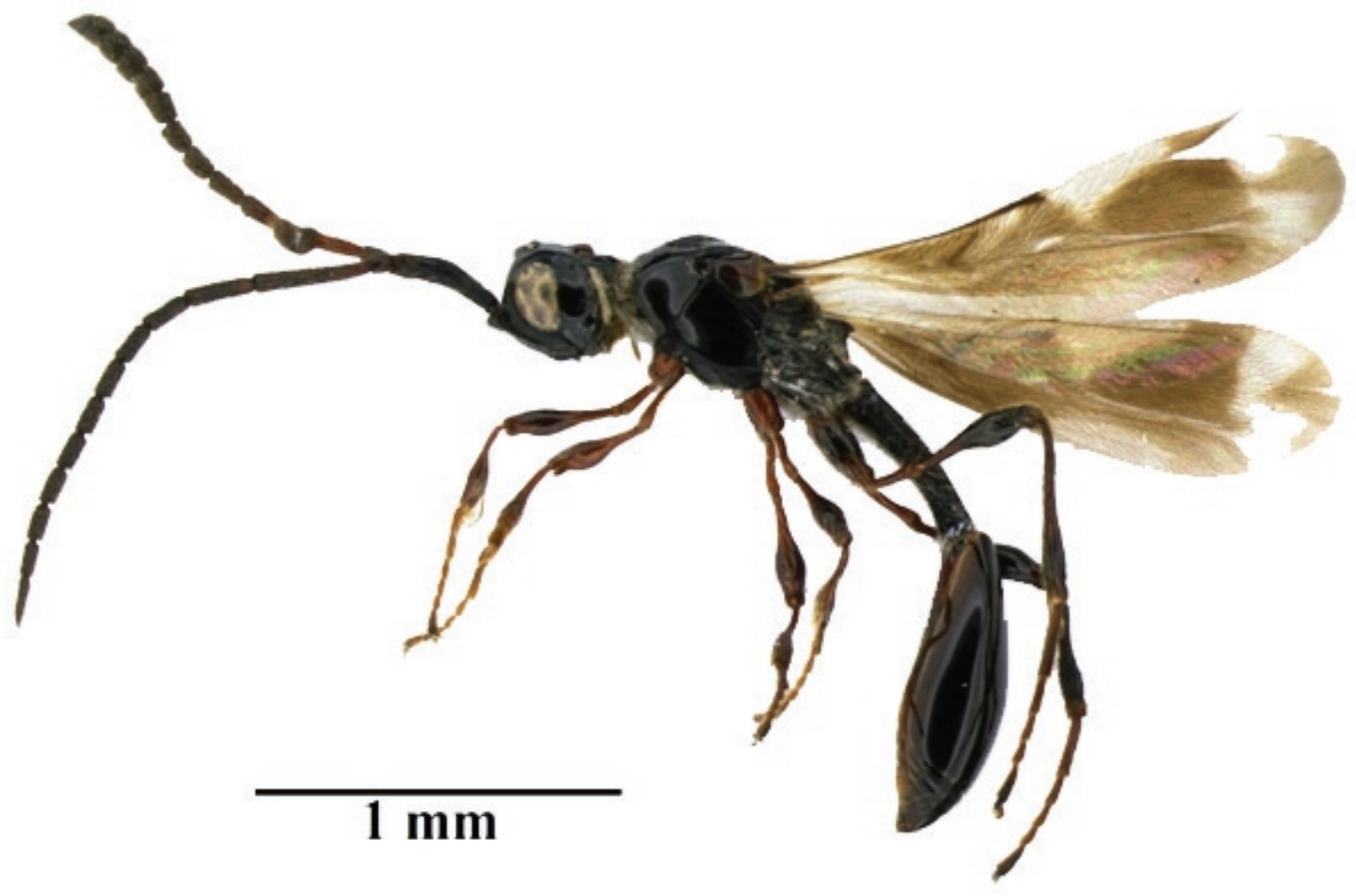

Figure 1. Gynandromorph female of Spilomicrus, habitus.
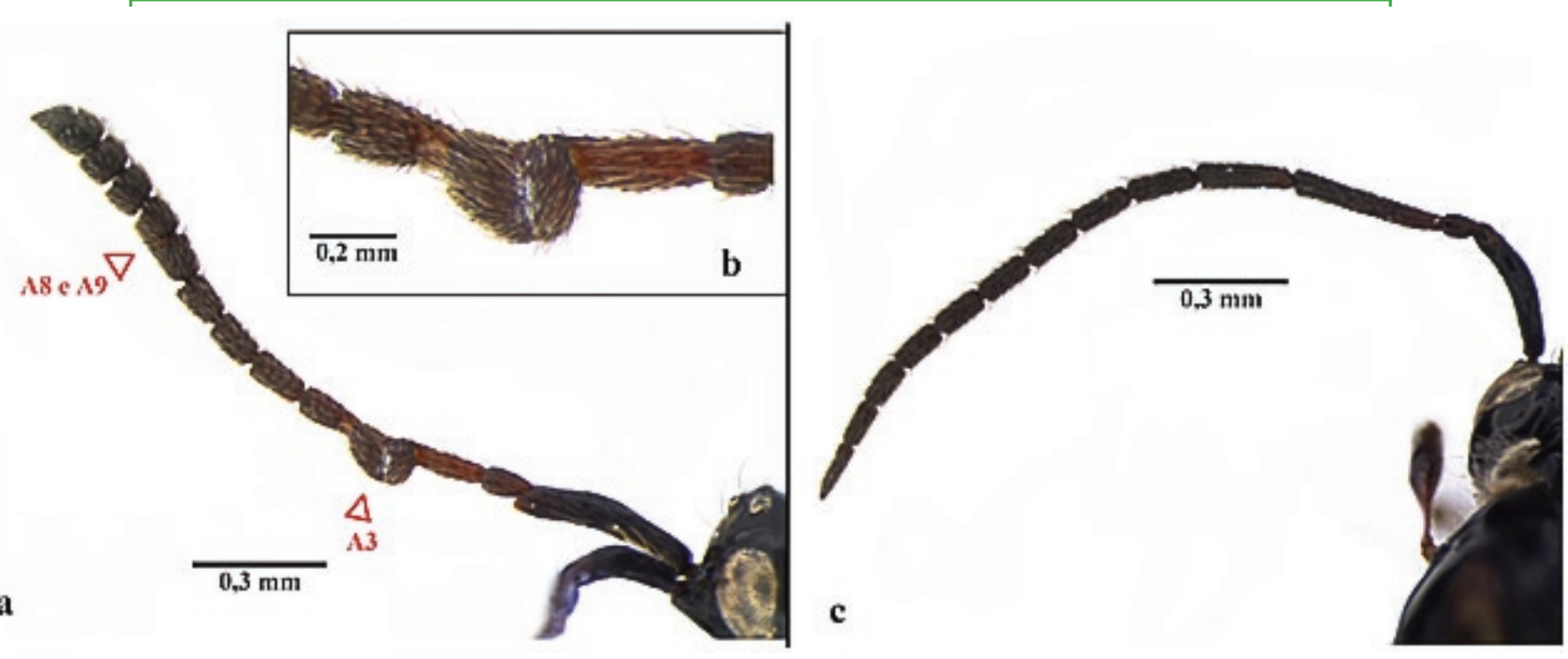

Figure 2. Anternnae of studied exemplar of Spilomicrus. a) Female antenna . b) Teratoma in the female antenna. c) Male antenna .

\section{ACKNOWLEDGMENTS}

We thank to the Instituto Nacional de Ciência e Tecnologia dos Hymenoptera Parasitoides da Região Sudeste Brasileira (Hympar/Sudeste - CNPq/Fapesp/Capes) for the financial support.

\section{REFERENCES}

Acosta, F.J. \& M.D. Martinez, 1984. Algunas anomalias en Leptothorax rabaudi Bond., 1818 (Hym., Formicidae). Boletín de la Asociación Española de Entomologia, 8: 41-45. Adlerz, G., 1908. Zwei Gynandromorphen von Anergates atratulus Schenk. Arkiv för Zoologi, 5: 1-6.

Akre, R.D., E.P. Catts, R.S. Zack \& X.C. Klostermeyer, 1982. Gynandromorphs of Megachile otundata (Fab.) 
(Hymenoptera: Megachilidae). Entomological News, 93: 8594.

Balazuc, J., 1948. La tératologie des coléoptères et expériences de transplantation sur Tenebrio molitor L. Mémoires du Muséum National d'Histoire Naturelle, 25: 1-293.

Balazuc, J., 1957. The tératologie des Hyménopteroides. Annales de la Société Entomologique de France, 126: 167-203.

Berndt, K.P. \& G. Kremer, 1983. New categories in the gynandromorphism of ants. Insectes Sociaux, 30: 461-465.

Beserra, E.B., Querino, R.B. \& J.R.P. Parra, 2003. Ocorrência de ginandromorfismo em Trichogramma pretiosum Riley (Hymenoptera: Trichogrammatidae). Neotropical Entomology, 32: 507-509.

Bessart, P., 1993. Un Conostigmus et un Ceraphron a antennes teratologiques (Hymenoptera: Ceraphronoidea). Bulletin de l'Institut Royal des Sciences Naturelles de Belgique Entomologie, 63: 51-58.

Bin, F., 1972. Un nuovo caso di ginandromorfismo in Ashmeadopria Kieffer (Hymenoptera, Proctotrupoidea, Diapriidae). Entomologica, 8: 55-59.

Bin, F., 1976. Record of a teratological Trichopria Ashm. (Hymenoptera, Diapriidae) Entomologica, 12: 67-70.

Borderá, S. \& J.Tormos., 1986. Un bracónidoy tres ichneumónidos teratológicos (Hym., Ichneumonoidea). Boletin de la Asociación Española de Entomologia, 10: 335-338.

Borsato, W., 1995. Segnalazione di una teratologia su Sulcopolistes sulcifer Zimmermann (Hymenoptera, Vespidae). Bollettino del Museo Civico di Storia Naturale di Verona, 19: 453-455.

Caltagirone, L.E., 1970. Gynandromorphism in the polyembryonic encyrtid Pentalitomastix plethoricus Cali. (Hymenoptera, Encyrtidae). Bollettino del Laboratorio di Entomologia Agraria Filippo Silvestri, 28: 98-112.

Ceballos, G., 1921. Nota sobre un himenóptero ginandromorfo. Memorias de la Real Sociedad Española de Historia Natural, tomo extraordinario: $79-81$.

Celary, W. \& B, Wisniowski, 2001. An interesting case of gynandromorphism in Andrena helvola (L., 1758) (Hymenoptera: Apoidea: Andrenidae). Folia Biologica, 49: 291-293.

Chitty, A.J., 1905. Exhibition of a hermaphrodite Proctotrupid. Transactions of the Entomological Society of London, 57: 65 .

Cooper, K.W., 1959. Abilaterallygynandromorphic Hypodynerus, and a summary of cytologic origins of such mosaic Hymenoptera. Biology of Eumeninae wasps, VI. Bulletin of the Florida State Museum, Biological Science, 5: 25-40.

Engel, M.S., 2007. A lateral gynandromorph in the bee genus Thyreus and the sting mechanism in the Melectini (Hymenoptera: Apidae). American Museum Novitates, 3553: 1-11.

Fabritius, K., 1968. Eine anomalie des abdomes bei der gattung Trimorus (Hym. Scelionidae). Analele Stiintifice ale Universitatii “Al. I. Cuza”, 14: 1-2.

Foerster, A., 1845. Notiz ueber einem Zwitter Diapria elegans Nees. Stettiner Entomologische Zeitung, 6: 390-392.

González, V., 2004. A gynandromorph of Megachile (Austromegachile) montezuma Cresson (Hymenoptera: Apoidea, Megachilidae). Entomotropica, 19: 155-156.

Halstead, J.A., 1988. A gynandromorph of Hockeria rubra (Ashmead) (Hymenoptera Chalcididae). Proceedings of the Entomological Society of Washington, 9: 258-259.

Huggert, L., 1977. Three gynandromorphic specimens of Idris piceiventris (Kieffer) (Hymenoptera, Proctotrupoidea: Scelionidae). Entomologica Scandinavica, 8: 158-160.

Laidlaw, W.B.R., 1932. A gynandromorphic form of Bombus, with other notes on bees and wasps in Scotland. Scottish Naturalist, 193: 25-27.

Leclercq, J., 1953. Un cas extraordinaire de gynandromorphisme chez Halictus sexcinctus (Hym. Apidae). Bulletin de l'Institut Royal des Sciences Naturelles de Belgique Entomologie, 29: 1-4.

Lucia, M., A.H., Abrahamovich \& L.J. Alvarez, 2009.
A gynandromorph of Xylocopa nigrocincta Smith (Hymenoptera: Apidae). Neotropical Entomology, 38: 155157.

Maeklin, F.W., 1956. Gynandromorphism in insects, with a description of a gynandromorphic Mutilla obscura Nyl. found in Helsingfors (Swedish). Linzer Biologische Beiträge, 3: $110-112$.

Martini A., N. Baldassarri \& P. Baronio, 1999. Gynandromorphism and its manifestations in Diprionid Hymenoptera. Bollettino dell'Istituto di Entomologia “Guido Grandi” dell’Università di Bologna, 53: 87-107.

Michel, B., 1985. Observations d'un cas de schistomélie antennaire chez Tenthredosis stigma F. (Hym., Tenthredinidae). L'Entomologiste, 41: 241-242

Michez, D., P. Rasmont, M. Terzo \& N.J. Vereecken, 2009. A synthesis of gynandromorphy among wild bees (Hymenoptera: Apoidea), with an annotated description of several new cases. Annales de la Société Entomologique de France, 45: 365375 .

Neumann, F.G., 1970. Abnormal Sirex noctilo F. (Hymenoptera: Siricidae). Journal of the Australian Entomological Society, 9: 168.

Nilsson, G.E., 1987. A gynandromorphic specimen of Evylaeus albipes (Fabricius) (Hymenoptera, Halictidae) and a discussion of possible causes of gynandromorphism in haplodiploid insects. Notulae Entomologicae, 67: 157-162.

Ogloblin, A.A., 1936. Un ginandromorfo de Acanthopria (Diapriidae, Hym.). Revista de la Sociedad Entomológica Argentina, 1: 33-36.

Ornosa, C., Cascales E. \& F.J. Ortiz-Sánchez, 2001. Nuevos casos teratológicos en Apoidea. Anales de Biología, 12: 19-24.

Peacock A.D., 1925. Studies in the parthenogenesis and sexuality of saw-flies (Tenthredinidae). II. A gynandromorph of Pterinoidea (Nematus) ribesii Scop. with observations on gynandromorphism and saw-fly sexuality. British Journal of Experimentalist Biology, 2: 61-84.

Penteado-Dias, A.M., Nunes, J.F. \& E.M. Shimbori, 2005. ObservationsonsometeratologicalBraconidae(Hymenoptera, Ichneumonoidea) from Brazil. Entomotropica, 20: 113-114.

Pereira, R.A.S., A.P. Prado \& F. Kjellberg, 2003. Gynandromorphism in pollinating fig wasps (Hymenoptera: Agaonidae). Entomological News, 114: 152-155.

Popovici, O.A., Mircea-Dan, M. \& N. David, 2014. New teratological cases in Platygastridae and Pteromalidae (Hymenoptera). Turkish Journal of Zoology, 38: 491-499. doi:10.3906/zoo-1312-30

Rajmohana,K.\&T.C.Narendran,1999.Aninterestingteratological Trichopria Ashmead (Diapriidae: Proctotrupoidea) from India. Zoos Print Journal, 14:94-96.

Safavi,M., 1968. Etudebiologiqueet ecologique des Hymenopteres parasites des oeufs des punaises des cereales. Entomophaga, 13: 381-496.

Savini, V. \& D. Furth, 2004. Teratologia en Coleoptera: un caso en Gioia bicolor (Blake, 1969) (Chrysomelidae, Alticinae) de Jamaica. Entomotropica, 19: 165-167.

Schneider, N. \& F. Feitz, 2003. Malformations observées chez quatre abeilles et neuf guêpes du Luxembourg (Hymenoptera, Aculeata). Bulletin de la Société des Naturalistes Luxembourgeois, 104: 95-98.

Scupola, A., 1994. Un caso di ginandromorfismo in Myrmica Latr. (Hymenoptera Formicidae). Bollettino della Società Entomologica Italiana, 125: 252-254.

Szabó, J.B., 1959. Notes on gynandromorph diapriid wasp from Hungary (Hym. Proct. Diapr.). Folia Entomologica Hungarica, (S.N.), 12-33: 495-496.

Tarasco, E., 1996. Un caso di ginandromorfismo in Coelichneumon rudis (Boyer de Fonscolombe, 1847) (Hymenoptera, Ichneumonidae). Entomologica, 30: 101-104.

Torre-Bueno,J.R., 1989. The Torre-Buenoglossary of entomology; compiled by Stephen W. Nichols; including Supplement A by Georges S. Tulloch. New York. The New York Entomological 
Society, xxii +840 p.

Turrisi, G.F. \& W. Borsato, 2008 Description of two gynandromorphic Eumenidae (Hymenoptera Vespoidea). Linzer Biologische Beiträge, 40: 951-957.

Turrisi, G.F., 1999. Un caso di ginandromorfismo in Myrmilla bison (A. Costa, 1887) Hymenoptera Mutillidae). Bollettino dell'Accademia Gioenia di Scienze Naturali di Catania, 31: 331-334.

Tussac, H. \& J. Balazuc, 1991. Anomalies de l'appareil visuel chez des Hyménoptères Apocrites. L’Entomologiste, 47: 49-52.

Tussac, H.. 1994. Une anomalie antennaire chez un Hyménoptère Symphyte. L'Entomologiste, 50: 313-314.

Wheeler, W.M., 1903. Some new gynandromorphous ants, with a review of the previously recorded cases. Bulletin of American Museum of Natural History, 19: 653-683.

Whiting, P.W. \& A.R. Whiting, 1927. Gynandromorphs and other irregular types in Habrobracon. Biological Bulletin, 52: 89120.

Wcislo, W.T., V.H. Gonzales \& L. Arneson, 2004. A review of deviant phenotypes in bees in relation to brood parasitism, and a gynandromorph of Megalopta genalis (Hymenoptera: Halictidae). Journal of Natural History, 38: 1443-1457.

Zhang, Y.Z. \& C.D. Zhu, 2007. A gynandromorph of Microterys ishiii (sic!) Tachikava (Hymenoptera: Chalcidoidea: Encyrtidae). Acta Entomologica Sinica, 50: 868-870.

\section{Received in: o7/29/2015}

Accepted in: 10/o1/2015

$* * * * * * * * * *$

\section{Suggestion citation:}

Comério, E.F., N.W. Perioto \& R.I.R. Lara, 2015. A Gynandromorph and Teratological Case in Spilomicrus sp. (Hymenoptera, Diaprioidea, Diapriidae). EntomoBrasilis, 8 (3): 249-252.

Available in: $\underline{\text { doi:10.12741/ebrasilis.v8i3.540 }}$
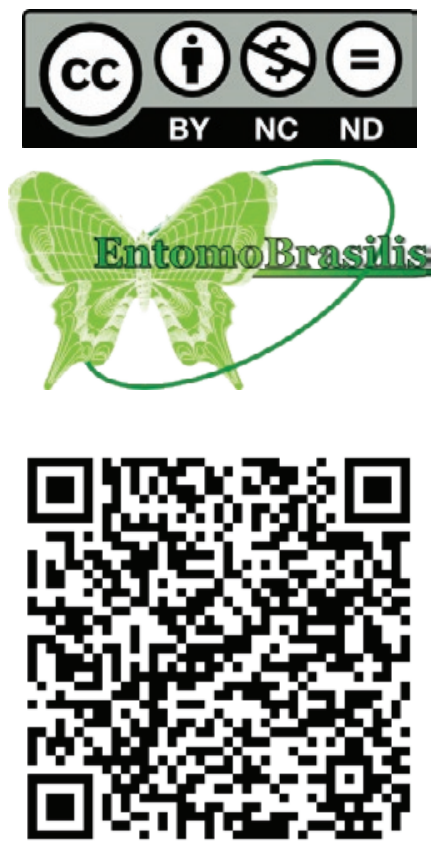